\title{
Spiroplasma penaei sp. nov., associated with mortalities in Penaeus vannamei, Pacific white shrimp
}

\author{
Linda M. Nunan, ${ }^{1}$ Donald V. Lightner, ${ }^{1}$ Marietta A. Oduori ${ }^{2}$ \\ and Gail E. Gasparich ${ }^{2}$ \\ ${ }^{1}$ Department of Veterinary Sciences and Microbiology, University of Arizona, Tucson, \\ AZ 85721, USA \\ ${ }^{2}$ Department of Biological Sciences, Towson University, Towson, MD 21252, USA
}

Correspondence

Linda M. Nunan

Imn@u.arizona.edu

\begin{abstract}
A new bacterial strain, designated SHRIMP ${ }^{\top}$, isolated from the haemolymph of the Pacific white shrimp, Penaeus vannamei, was serologically distinct from other spiroplasmas. Cells of this strain were helical in form and variable in length. Examination by electron microscopy revealed wall-less cells delineated by a single cytoplasmic membrane. The organisms grew well in M1D media supplemented with $2 \% \mathrm{NaCl}$. Strain $\mathrm{SHRIMP}^{\top}$ grew at temperatures of $20-37^{\circ} \mathrm{C}$, with optimum growth occurring at $28^{\circ} \mathrm{C}$. The strain catabolized glucose and hydrolysed arginine, but did not hydrolyse urea. The $\mathrm{G}+\mathrm{C}$ content of the DNA was $29 \pm 1$ mol\%. Strain SHRIMP ${ }^{\top}$ (=ATCC BAA $-1082^{\top}=$ CAIM $1252^{\top}$ ) is designated the type strain of a novel species, Spiroplasma penaei sp. nov., which represents a new subgroup (I-9) of the group I spiroplasmas.
\end{abstract}

In international trade, the most prominent product from aquaculture is marine shrimp, of which approximately $26 \%$ of the total product comes from pond-reared penaeid species (FAO, 2002). Penaeus vannamei (taxonomy according to Holthuis, 1980), the Pacific white shrimp, is one of the predominant species of farm-raised shrimp cultivated in both the eastern and the western hemispheres. As with any monoculture, raising shrimp in ponds in close proximity to each other increases the spread of diseases (Kautsky et al., 2000), and disease has been attributed as the single largest source of economic loss in the aquaculture industry (Meyer, 1991). Cultured penaeid shrimp are susceptible to viral, rickettsial, bacterial, fungal, protozoan and metazoan infectious pathogens (Lightner, 1993). The most severe diseases of shrimp, causing the greatest economic losses to growers, are caused by viruses and bacteria (Lightner et al., 1992).

In January 2002, severe mortalities of P. vannamei occurred in one pond at a Colombian shrimp farm located on the Caribbean coast. During the following stocking period in May-June 2002, two additional shrimp ponds at the same farm experienced high mortalities. The pathogenic spiroplasma identified as the causative agent spread during the

Published online ahead of print on 1 July 2005 as DOI 10.1099/ ijs.0.63555-0.

Abbreviations: SPF, specific pathogen-free; TEM, transmission electron microscopy.

The GenBank/EMBL/DDBJ accession number for the 16S rRNA gene sequence of strain SHRIMP ${ }^{\top}$ is AY771927. next grow-out cycle to a neighbouring farm, which suffered mortalities ranging from 10 to $90 \%$.

Upon receipt of infected specimens from Colombia preserved in Davidson's alcohol-formalin-acetic acid, histological analysis was performed (Bell \& Lightner, 1988). The presumptive diagnosis for the mortalities suffered was attributed to a severe bacterial infection. This diagnosis was further confirmed with the use of a universal digoxigeninlabelled bacterial probe and in situ hybridization assays (Nunan et al., 2004). Tissue from frozen infected $P$. vannamei from the initial epizootic was sampled for DNA extraction. Using universal $16 \mathrm{~S}$ rRNA primers and PCR, the $16 \mathrm{~S}$ rRNA gene of the bacterium was sequenced (Nunan et al., 2003). The sequence was submitted to GenBank and compared with other bacterial $16 \mathrm{~S}$ rRNA genes. The results from a BLAST search revealed 16S rRNA gene sequence similarity of $99 \%$ to Spiroplasma insolitum.

The large genus Spiroplasma is a group of wall-less eubacteria displaying a helical cell morphology. Spiroplasmas are motile, even though they lack flagella (Davis \& Worley, 1973; Daniels et al., 1980; Trachtenberg, 1998). These bacteria have historically been associated with plants and arthropods, primarily insects and ticks (Clark, 1982; Tully et al., 1982; Williamson et al., 1989, 1998; Tully \& Whitcomb, 1990), but more recently members of this genus have been discovered in the Chinese mitten crab (Eriocheir sinensi) (Wang et al., 2003, 2004) and the deep-sea alvinocarid shrimp Rimicaris exoculata (Zbinden \& Cambon-Bonavita, 2003). Spiroplasmas can be pathogenic 
in plants and insects, and cause 'tremor disease' in freshwater mitten crabs (Wang et al., 2003). The Spiroplasma species associated with the marine alvinocarid shrimp appears to be part of the normal gut flora. In this paper, we present the results of a taxonomic study of the causative organism of the P. vannamei epizootic in Colombia. We present supporting data for the basis of the proposed minimal requirements for assignment of binomial names to mollicutes. The strain investigated, designated SHRIMP $^{\mathrm{T}}$, is considered to be the type strain of a proposed novel species, Spiroplasma penaei sp. nov. S. penaei is the first pathogenic spiroplasma to be isolated from a marine crustacean.

\section{Spiroplasma strains}

The method used initially to isolate strain SHRIMP ${ }^{\mathrm{T}}$ from the infected $P$. vannamei and the resultant mortalities observed experimentally have been described previously (Nunan et al., 2004). Briefly, the strain was cultivated by injection of a tissue homogenate, produced from frozen, naturally infected $P$. vannamei from Colombia, into specific pathogen-free (SPF) (Wyban et al., 1992; Pruder et al., 1995) P. vannamei, which in turn became infected. Frozen tissue $(1 \mathrm{~g})$ from the infected shrimp was sampled and homogenized in $5 \mathrm{ml}$ Tris $/ \mathrm{NaCl}$ buffer. The homogenate was diluted $1: 5$ with sterile $2 \%$ saline and injected into the third abdominal segment of SPF P. vannamei. As shrimp became moribund, haemolymph was drawn by using a $25 \mathrm{~g}$ needle attached to a $1 \mathrm{ml}$ syringe. The haemolymph was filtered through a $0.45 \mu \mathrm{m}$ Acrodisc syringe filter (Pall Corporation) and added to M1D medium (Jones et al., 1977; Whitcomb et al., 1982) supplemented with $2 \% \mathrm{NaCl}$, and then incubated at $30{ }^{\circ} \mathrm{C}$. Following growth in the medium, as visualized by the phenol red component of the medium changing first to orange and then to yellow, the spiroplasma was examined by transmission electron microscopy (TEM) (Nunan et al., 2004). The cultured organism was triply cloned and used to infect additional SPF P. vannamei. The triply cloned spiroplasma culture $(1 \mathrm{ml})$ was centrifuged for $3 \mathrm{~min}$ at $3000 \mathrm{~g}$. The supernatant fluid was discarded and the bacterial pellet was resuspended in sterile $2 \%$ saline. This inoculum was injected into the SPF shrimp. As mortalities occurred, shrimp were sampled for histological assessment and haemolymph was drawn for culture and TEM, as described previously (Nunan et al., 2004). Recovery of the organism and associated mortalities fulfilled Koch's postulates.

\section{Culture media and cultivation techniques}

The primary culture from which strain SHRIMP $^{\mathrm{T}}$ was isolated was grown at $30^{\circ} \mathrm{C}$ in $\mathrm{M} 1 \mathrm{D}$ liquid medium (Whitcomb, 1983) supplemented with $2 \% \mathrm{NaCl}$. After several passages, the isolate was triply cloned (Tully, 1983). This cloned isolate was designated SHRIMP ${ }^{\mathrm{T}}$ and was used in all subsequent characterization studies and also for the fulfilment of Koch's postulates. Temperature requirements for growth were assessed by the method of Konai et al. (1996). In addition, Serum Fraction (SF) medium, supplemented with $2 \% \mathrm{NaCl}$, was used for all biochemical tests (Aluotto et al., 1970).

\section{Morphological studies}

Cells of strain SHRIMP ${ }^{\mathrm{T}}$ from cultures in the exponential phase of growth were examined by dark-field microscopy (magnification, $\times 1000$ ). Material for electron microscopy was established by pelleting $1 \mathrm{ml}$ from a $24 \mathrm{~h}$ triple-clone culture at $3000 \mathrm{~g}$ for $3 \mathrm{~min}$. The M1D medium was removed and replaced immediately with $1 \mathrm{ml}$ cold $4 \%$ buffered glutaraldehyde, prepared with $0 \cdot 15 \mathrm{M}$ Millonig's phosphate buffer $(\mathrm{pH} 7 \cdot 0)$ and supplemented with $1 \% \mathrm{NaCl}$ and $0.5 \%$ sucrose (Lightner, 1996). Following $1 \mathrm{~h}$ refrigeration $\left(4^{\circ} \mathrm{C}\right)$, the glutaraldehyde buffer was replaced with cold Millonig's phosphate buffer $(0 \cdot 15 \mathrm{M})$ and maintained at $4{ }^{\circ} \mathrm{C}$ until post-fixation. The pellet was then post-fixed with $1 \%$ phosphate-buffered osmium tetroxide, dehydrated in ethyl alcohol and embedded in Spurr's resin (Ladd Research Inc.). The embedded pellet was sectioned to 75-90 nm thickness, stained with lead citrate and uranyl acetate and viewed by using a JEOL JEM 100CXII electron microscope, operated at $60 \mathrm{kV}$ (Fig. 1).

\section{Biological and biochemical properties}

Procedures for determining carbohydrate fermentation and arginine and urea hydrolysis were as described by Aluotto et al. (1970). Filtration characteristics (Tully, 1983) were determined by using mid-logarithmic cultures grown in M1D medium.

\section{Serological tests}

Anitserum to strain SHRIMP $^{\mathrm{T}}$ was raised in rabbits as described by Williamson et al. (1979). The spiroplasmadeformation test (Williamson et al., 1978) and metabolisminhibition test were used to compare strain SHRIMP ${ }^{\mathrm{T}}$ serologically with the type strains from all recognized Spiroplasma groups and subgroups. Hyperimmune antisera to all recognized Spiroplasma groups and subgroups are maintained in the Towson University Spiroplasma Reference Collection. Reciprocal tests were performed with strains for which antisera reacted with the SHRIMP ${ }^{\mathrm{T}}$ strain.

\section{Genomic analysis}

Extraction and purification of DNA from spiroplasmas was performed as described previously (Gasparich et al., 1993). The DNA was diluted in $1 \times$ SSC buffer to a final sodium concentration of $0 \cdot 195 \mathrm{M}$. This sample was used (with a $1 \times$ SSC buffer blank) in a Cary Varian thermal spectrophotometer equipped with software to determine the melting temperature, and the DNA $\mathrm{G}+\mathrm{C}$ content was determined (Carle et al., 1983). This process was repeated twice and a control of Escherichia coli DNA in $1 \times$ SSC buffer was used to verify the results. 


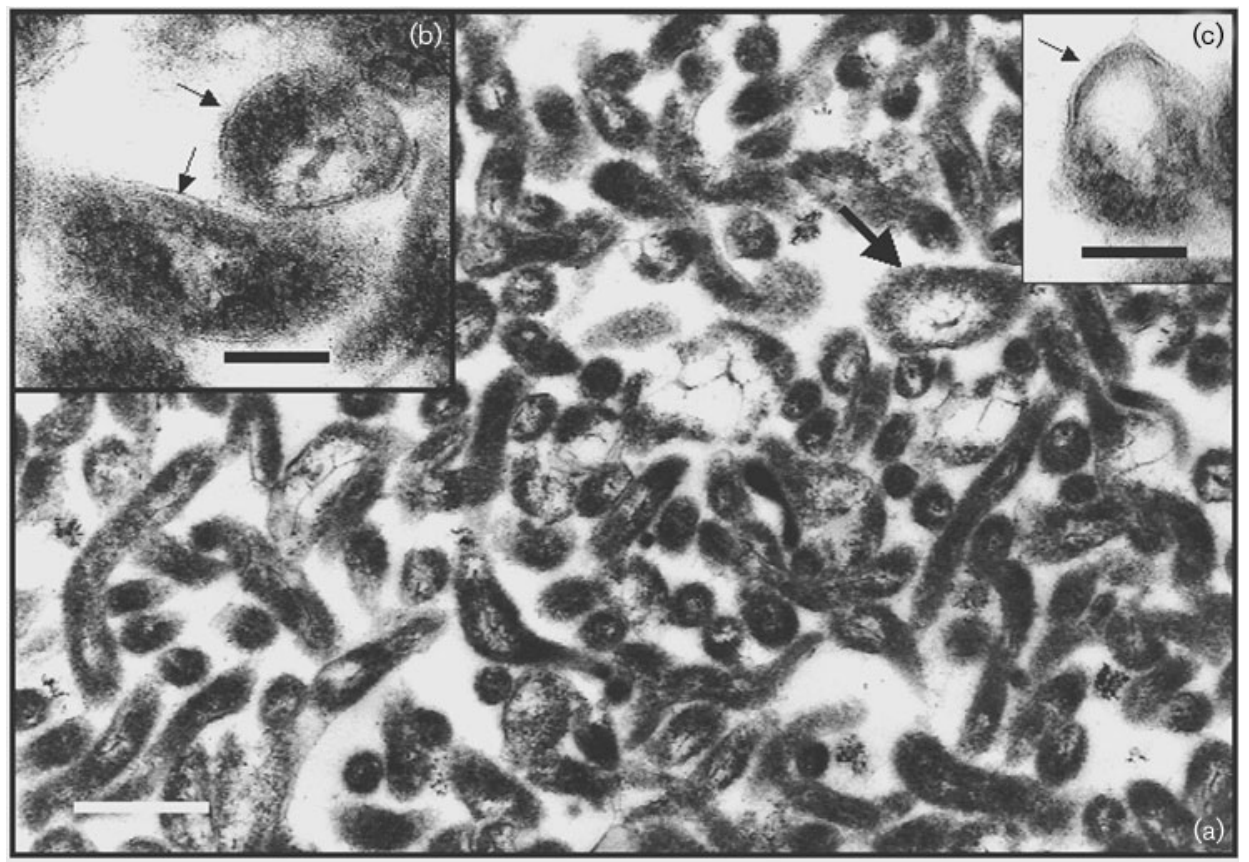

Fig. 1. Electron micrographs of the sectioned and stained pellet from strain SHRIMP'. The sections were stained with lead citrate and uranyl acetate. (a) The large arrow indicates a spiroplasma bleb. Bar, $0.5 \mu \mathrm{m}$. (b, c) The small arrows indicate the single cytoplasmic membrane. Bars, $0 \cdot 1 \mu \mathrm{m}$.

\section{Phylogenetic analysis}

The 16S rRNA gene sequences used in this study with their GenBank accession numbers and ATCC culture collection accession numbers are indicated in Fig. 2. Sequences were aligned by using CLUSTAL W (Thompson et al., 1994) and then aligned manually in MACCLADE (Maddison \& Maddison, 1992). A 1000-replicate bootstrap analysis was performed by using a heuristic search and the tree bisection-reconnection maximum-parsimony algorithm in PAUP (version 4.0b10; Swofford, 1998).

\section{Cultural and morphological properties}

Strain SHRIMP ${ }^{\mathrm{T}}$ grew well in M1D broth and SF media (both supplemented with $2 \% \mathrm{NaCl}$ ) and was resistant to $500 \mathrm{U}$ penicillin $\mathrm{ml}^{-1}$ in both media. Growth occurred over a temperature range of $20-37^{\circ} \mathrm{C}$, with optimal growth at

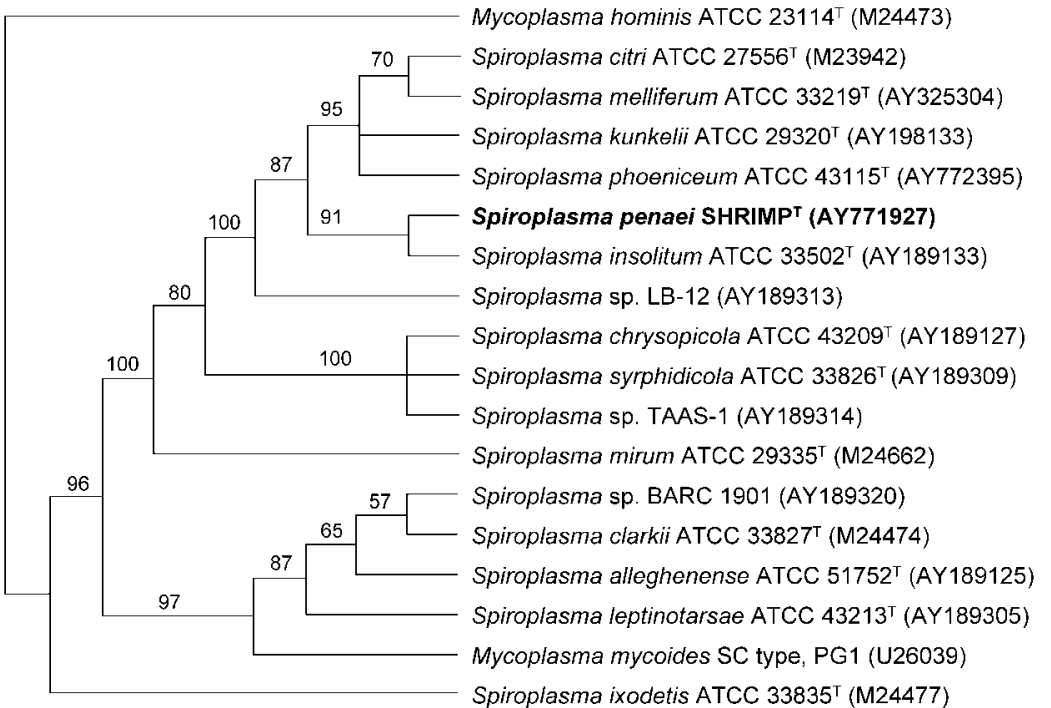

Fig. 2. Phylogenetic tree showing the position of $S$. penaei SHRIMP ${ }^{\top}$ among representatives of the genera Spiroplasma and Mycoplasma. Mycoplasma hominis and Mycoplasma pulmonis were used as outgroup strains. A total of 1515 positions were used in the analysis, with the tree bisection-reconnection maximum-parsimony algorithm for branch swapping. The dataset was resampled 1000 times and bootstrap percentage values are given at the nodes. GenBank accession numbers are given in parentheses. All type strains were obtained from the ATCC. The 16S rRNA gene sequence of $S$. penaei $\mathrm{SHRIMP}^{\top}$ was included in a dataset described previously (Gasparich et al., 2004). 
$28^{\circ} \mathrm{C}$. As determined by dark-field microscopy, logarithmicphase cultures of strain SHRIMP $^{\mathrm{T}}$ in M1D medium contained numerous long, helical, motile filaments. As determined by electron microscopy of logarithmic-phase cultures grown in M1D medium, cells of strain SHRIMP were filamentous with no evidence of a cell wall (Fig. 1b, c). The mean cell diameter was $195 \mathrm{~nm}(n=20$; range, $160-230 \mathrm{~nm}$ ). Cells were surrounded by a single cytoplasmic membrane. Vesicular blebs are also displayed (Fig. 1a), very similar in appearance to those described previously from Spiroplasma citri (Razin et al., 1973).

\section{Biochemical and biological properties}

Strain SHRIMP $^{\mathrm{T}}$ was able to grow in media containing glucose, glucose and arginine, and arginine alone, indicating abilities to ferment glucose with the production of acid and to catabolize arginine. A test was considered to be positive when the organism was able to grow in ten successive passages into the test medium. No growth was observed in unsupplemented SF medium or urea, and therefore urea hydrolysis was not tested. Cultures grew after passage through $220 \mathrm{~nm}$ filters, but not after passage through $100 \mathrm{~nm}$ filters.

\section{Serological studies}

Metabolism-inhibition and spiroplasma-deformation tests indicated that strain SHRIMP ${ }^{\mathrm{T}}$ was unrelated serologically to representatives of recognized Spiroplasma groups or species. Antigens and antisera of strain $\mathrm{SHRIMP}^{\mathrm{T}}$ were tested in all combinations against all recognized and putative groups and subgroups. Strains R8A2 (I-1), E275 (I-3), 277F (I-4), LB-12 (I-5) and P40 (I-8) showed only minimal serological cross-reactivity at a 20 -fold dilution titre, but at no higher titres. All other reactions were negative. Reaction of strain SHRIMP ${ }^{\mathrm{T}}$ antiserum against strain SHRIMP $^{\mathrm{T}}$ culture was to a dilution of 5120 .

\section{DNA base composition}

The mean $T_{\mathrm{m}}$ value for strain $\mathrm{SHRIMP}^{\mathrm{T}}$ DNA was $81 \cdot 8^{\circ} \mathrm{C}$, resulting in a base composition ( $\mathrm{G}+\mathrm{C}$ content) of $29 \pm 1 \mathrm{~mol} \%$. The E. coli standard measurements averaged $45 \pm 1 \mathrm{~mol} \%$.

\section{Phylogenetic analysis}

Fig. 2 shows the phylogenetic tree constructed by using maximum parsimony. The dataset was resampled 1000 times and bootstrap percentage values are indicated for each branch. Strain SHRIMP ${ }^{\mathrm{T}}$ groups consistently with the group I spiroplasma cluster and is associated most closely with S. insolitum, which is the type species for subgroup 6 of the group I spiroplasmas (Hackett et al., 1993). All strains within the group I cluster are pathogenic to plants, insects or now shrimp. This is also consistent with findings from the serological analyses, in which there was a very minor reaction with the subgroup I-6 antisera.

\section{Habitat and pathogenicity}

Strain SHRIMP ${ }^{\mathrm{T}}$ was isolated from the haemolymph of the Pacific white shrimp, P. vannamei. This pathogenic strain was first recognized in February 2002 in two shrimp ponds in Colombia. The marine shrimp were being cultured in a low-salinity (2-10 parts per million) region. The initial outbreak occurred during a period of unusually high temperatures, with the pond water reaching $37^{\circ} \mathrm{C}$ for more than $3 \mathrm{~h}$ each day for over 2 weeks. Mortalities from the initial epizootic were highly variable and ranged from 20-30 to $60-70 \%$. To examine the pathogenicity of the spiroplasma, infectivity studies were initially performed by injecting a tissue homogenate from the infected Colombian shrimp into SPF P. vannamei (Nunan et al., 2004). As shrimp began to die and were moribund, haemolymph was extracted, filtered and added to M1D medium. The medium-cultured spiroplasma was then injected into SPF $P$. vannamei. To complete Koch's postulates, haemolymph was again sampled from moribund shrimp, filtered, added to M1D medium and examined by TEM, following 3 days growth, for the presence of the spiroplasma.

The properties described here for strain SHRIMP $^{\mathrm{T}}$ fulfil the proposed criteria (ICSB, 1995) for species of the class Mollicutes, including the absence of a cell wall, filterability and penicillin resistance. The helicity and motility of cells of this organism, as well as its inability to hydrolyse urea, indicate that it is a member of the family Spiroplasmataceae in the order Entomoplasmatales (Tully et al., 1993). Serological comparisons of strain SHRIMP ${ }^{\mathrm{T}}$ with representatives of all of the major Spiroplasma species, groups and subgroups demonstrated the uniqueness of the strain. We therefore propose the name Spiroplasma penaei sp. nov. for this organism.

\section{Description of Spiroplasma penaei sp. nov.}

Spiroplasma penaei (penae'i. N.L. n. Penaeus a genus of penaeid shrimp; N.L. gen. n. penaei of Penaeus vannamei, from which the organism was isolated).

Cells are helical and motile filaments with a mean diameter of $195 \mathrm{~nm}$. Cells lack true cell walls. Acid is produced from glucose. Temperature range for growth is $20-37^{\circ} \mathrm{C}$ and optimum growth occurs at $28^{\circ} \mathrm{C}$ in M1D broth. Serologically distinct from previously characterized Spiroplasma species. Pathogenicity is indicated by injection into $P$. vannamei. The $\mathrm{G}+\mathrm{C}$ content of the DNA is $29 \pm 1 \mathrm{~mol} \%$.

The type strain, SHRIMP $^{\mathrm{T}}\left(=\right.$ ATCC BAA $-1082^{\mathrm{T}}=$ CAIM $1252^{\mathrm{T}}$ ), was isolated from the haemolymph of the Pacific white shrimp, P. vannamei.

\section{Acknowledgements}

We thank Bonnie Poulos, Rita Redman and David Bentley for technical assistance. Funding for this research was provided by a grant from the USMSFP, USDA, CSREES, grant no. 2002-38808-01345. 


\section{References}

Aluotto, B. B., Wittler, R. G., Williams, C. O. \& Faber, J. E. (1970). Standardized bacteriologic techniques for the characterization of Mycoplasma species. Int J Syst Bacteriol 20, 35-58.

Bell, T. A. \& Lightner, D. V. (1988). A Handbook of Normal Penaeid Shrimp Histology, p. 6. Baton Rouge, LA: World Aquaculture Society.

Carle, P., Saillard, C. \& Bové, J. M. (1983). Determination of guanine plus cytosine content of DNA. Methods Mycoplasmol 1, 301-308.

Clark, T. B. (1982). Spiroplasmas: diversity of arthropod reservoirs and host-parasite relationships. Science 217, 57-59.

Daniels, M. J., Longland, J. M. \& Gilbart, J. (1980). Aspects of motility and chemotaxis in spiroplasmas. J Gen Microbiol 118, 429-436.

Davis, R. E. \& Worley, J. F. (1973). Spiroplasma: motile, helical microorganism associated with corn stunt disease. Phytopathology 63, 403-408.

FAO (Food \& Agriculture Organization of the United Nations) (2002). The State of World Fisheries and Aquaculture (SOFIA). Rome: FAO.

Gasparich, G. E., Hackett, K. J., Stamburski, C., Renaudin, J. \& Bové, J. M. (1993). Optimization of methods for transfecting Spiroplasma citri strain R8A2 HP with the spiroplasma virus SpV1 replicative form. Plasmid 29, 193-205.

Gasparich, G. E., Whitcomb, R. F., Dodge, D., French, F. E., Glass, J. \& Williamson, D. L. (2004). The genus Spiroplasma and its nonhelical descendants: phylogenetic classification, correlation with phenotype and roots of the Mycoplasma mycoides clade. Int J Syst Evol Microbiol 54, 893-918.

Hackett, K. J., Whitcomb, R. F., Tully, J. G. \& 9 other authors (1993). Spiroplasma insolitum sp. nov., a new species of group I spiroplasma with an unusual DNA base composition. Int $J$ Syst Bacteriol 43, 272-277.

Holthuis, L. B. (1980). Shrimp and Prawn of the World (FAO species catalog, vol. 1). FAO Fish Synop. 125. Rome: FAO.

ICSB (International Committee on Systematic Bacteriology Subcommittee on the Taxonomy of Mollicutes) (1995). Revised minimum standards for description of new species of the class Mollicutes (division Tenericutes). Int J Syst Bacteriol 45, 605-612.

Jones, A. L., Whitcomb, R. F., Williamson, D. L. \& Coan, M. E. (1977). Comparative growth and primary isolation of spiroplasmas in media based on insect tissue culture formulations. Phytopathology 67, 738-746.

Kautsky, N., Ronnback, P., Tedengren, M. \& Troell, M. (2000). Ecosystem perspectives on management of disease in shrimp pond farming. Aquaculture 191, 145-161.

Konai, M., Clark, E. A., Camp, M., Koeh, A. L. \& Whitcomb, R. F. (1996). Temperature ranges, growth optima, and growth rates of Spiroplasma (Spiroplasmataceae, class Mollicutes) species. Curr Microbiol 32, 314-319.

Lightner, D. V. (1993). Diseases of cultured penaeid shrimp. In $C R C$ Handbook of Mariculture: Crustacean Aquaculture, 2nd edn, vol. 1, pp. 393-486. Edited by J. P. McVey. Boca Raton, FL: CRC Press.

Lightner, D. V. (1996). A Handbook of Shrimp Pathology and Diagnostic Procedures for Diseases of Cultured Penaeid Shrimp (Special Publication of the World Aquaculture Society). Baton Rouge, LA: World Aquaculture Society.

Lightner, D. V., Bell, T. A., Redman, R. M., Mohney, L. L., Natividad, J. M., Rukyani, A. \& Poernomo, A. (1992). A review of some major diseases of economic significance in penaeid prawns/shrimps of the Americas and Indopacific. In Diseases in Asian Aquaculture, pp. 57-80. Edited by I. M. Shariff, R. P. Subasinghe \& J. R. Arthur. Manila, Philippines: Fish Health Section, Asian Fisheries Society.
Maddison, W. P. \& Maddison, D. R. (1992). MACCLADE: Analysis of Phylogeny and Character Evolution, version 3.0. Sunderland, MA: Sinauer Associates.

Meyer, F. P. (1991). Aquaculture disease and health management. J Anim Sci 69, 4201-4208.

Nunan, L. M., Poulos, B., Redman, R., Le Groumellec, M. \& Lightner, D. V. (2003). Molecular detection methods developed for a systemic rickettsia-like bacterium (RLB) in Penaeus monodon (Decapoda: Crustacea). Dis Aquat Organ 53, 15-23.

Nunan, L. M., Pantoja, C. R., Salazar, M., Aranguren, F. \& Lightner, D. V. (2004). Characterization and molecular methods for detection of a novel spiroplasma pathogenic to Penaeus vannamei. Dis Aquat Organ 62, 255-264.

Pruder, G. D., Brown, C. L., Sweeney, J. M. \& Carr, W. H. (1995). High health shrimp systems: seed supply - theory and practice. In Swimming Through Troubled Water: Proceedings of the Special Session on Shrimp Farming, Aquaculture '95, pp. 40-52. Edited by C. L. Browdy \& J. S. Hopkins. Baton Rouge, LA: World Aquaculture Society.

Razin, S., Hasin, M., Ne'eman, Z. \& Rottem, S. (1973). Isolation, chemical composition, and ultrastructural features of the cell membrane of the mycoplasma-like organism Spiroplasma citri. $J$ Bacteriol 116, 1421-1435.

Swofford, D. L. (1998). PAUP*: Phylogenetic Analysis Using Parsimony (*and Other Methods), version 4. Sunderland, MA: Sinauer Associates.

Thompson, J. D., Higgins, D. G. \& Gibson, T. J. (1994). CLUSTAL W: improving the sensitivity of progressive multiple sequence alignment through sequence weighting, position-specific gap penalties and weight matrix choice. Nucleic Acids Res 22, 4673-4680.

Trachtenberg, S. (1998). Mollicutes - wall-less bacteria with internal cytoskeletons. J Struct Biol 124, 244-256.

Tully, J. G. (1983). Cloning and filtration techniques for mycoplasmas. Methods Mycoplasmol 1, 173-177.

Tully, J. G. \& Whitcomb, R. F. (1990). The genus Spiroplasma. In The Prokarotes, pp. 1960-1980. Edited by M. P. Starr, H. Stolp, H. G. Trüper, A. Balows \& H. G. Schlegel. New York: Springer.

Tully, J. G., Whitcomb, R. F., Rose, D. L. \& Bové, J. M. (1982). Spiroplasma mirum, a new species from the rabbit tick (Haemaphysalis leporispalustris). Int J Syst Bacteriol 32, 92-100.

Tully, J. G., Bové, J. M., Laigret, F. \& Whitcomb, R. F. (1993). Revised taxonomy of the class Mollicutes: proposed elevation of a monophyletic cluster of arthropod-associated mollicutes to ordinal rank (Entomoplasmatales ord. nov.), with provision for familial rank to separate species with nonhelical morphology (Entomoplasmataceae fam. nov.) from helical species (Spiroplasmataceae), and emended descriptions of the order Mycoplasmatales, family Mycoplasmataceae. Int J Syst Bacteriol 43, 378-385.

Wang, W., Rong, L., Gu, W., Du, K. \& Chen, J. (2003). Study on experimental infections of Spiroplasma from the Chinese mitten crab in crayfish, mice and embryonated chickens. Res Microbiol 154, 677-680.

Wang, W., Chen, J., Du, K. \& Xu, Z. (2004). Morphology of spiroplasmas in the Chinese mitten crab Eriocheir sinensis associated with tremor disease. Res Microbiol 155, 630-635.

Whitcomb, R. F. (1983). Culture media for spiroplasmas. Methods Mycoplasmol 1, 147-158.

Whitcomb, R. F., Tully, J. G., Rose, D. L., Stephens, E. B., Smith, A., McCoy, R. E. \& Barile, M. F. (1982). Wall-less prokaryotes from fall flowers in central United States and Maryland. Curr Microbiol 7, 285-290.

Williamson, D. L., Whitcomb, R. F. \& Tully, J. G. (1978). The spiroplasma deformation test, a new serological method. Curr Microbiol 1, 203-207. 
Williamson, D. L., Tully, J. G. \& Whitcomb, R. F. (1979). Serological relationships of spiroplasmas as shown by combined deformation and metabolism inhibition tests. Int J Syst Bacteriol 29, 345-351.

Williamson, D. L., Tully, J. G. \& Whitcomb, R. F. (1989). The genus Spiroplasma. In The Mycoplasmas, vol. 5, pp. 71-111. Edited by R. F. Whitcomb \& J. G. Tully. San Diego, CA: Academic Press.

Williamson, D. L., Whitcomb, R. F., Tully, J. G. \& 10 other authors

(1998). Revised group classification of the genus Spiroplasma. Int J Syst Bacteriol 48, 1-12.
Wyban, J. A., Swingle, J. S., Sweeney, J. N. \& Pruder, G. D. (1992). Development and commercial performance of high health shrimp using specific pathogen free (SPF) broodstock Penaeus vannamei. In Proceedings of the Special Session on Shrimp Farming, pp. 254-259. Edited by J. A. Wyban. Baton Rouge, LA: World Aquaculture Society.

Zbinden, M. \& Cambon-Bonavita, M.-A. (2003). Occurrence of Deferribacterales and Entomoplasmatales in the deep-sea alvinocarid shrimp Rimicaris exoculata gut. FEMS Microbiol Ecol 46, 23-30. 